\title{
Kızıltepe İleri Biyolojik Atıksu Arıtma Tesisi'nin KOİ, BOİ 5 ve AKM Yönünden İşletme Verimliliğinin Değerlendirilmesi
}

\author{
Şule Tatar $^{1 *}$, Mehmet Nedim Sağlam² \\ 1"Munzur Üniversitesi, Tunceli Meslek Yüksekokulu, Laboratuvar Teknolojileri Bölümü,Tunceli, Türkiye,(ORCID: 0000-0001-8962-0107), sytatar@munzur.edu.tr \\ ${ }^{2}$ Munzur Üniversitesi, Mühendislik Fakültesi, Çevre Mühendisliği Bölümü, Tunceli, Türkiye (ORCID: 0000-0002-4315-5964), mnedimsaglam@hotmail.com
}

(İlk Geliş Tarihi 16 Temmuz 2020 ve Kabul Tarihi 9 Ekim 2020)

(DOI: 10.31590/ejosat.770260)

ATIF/REFERENCE: Tatar, Ş. \& Sağlam, M.N. (2020). Kızıltepe İleri Biyolojik Atıksu Arıtma Tesisi'nin KOİ, BOİ 5 ve AKM Yönünden İşletme Verimliliğinin Değerlendirilmesi. Avrupa Bilim ve Teknoloji Dergisi, (20), 265-269.

\section{Öz}

Son yıllarda kentleşme oranının artmasıyla evsel nitelikli atıksular, çevre kirliliğinin ortaya çıkmasında rol oynayan önemli sebeplerden biri haline gelmiştir. Kentsel atıksu arıtma tesisleri bu kirliliği engellemek için yapılmış olan, evsel nitelikli atıksuların aktarılacağı alıcı ortama varmadan önce zararlı etkilerini engelleyen veya olabilecek en düşük seviyeye indiren tesislerdir. Bu çalışmada Kızıltepe Biyolojik Atıksu Arıtma Tesisi'nde 8 ay boyunca günlük tesis giriş ve çıkışından alınan 24 saatlik kompozit numuneler ile KOİ, BOİ 5 ve AKM parametreleri analiz edilmiş ve tesis verimliliği gözlemlenmiştir. Buna göre tesis; \%93 KOİ, \%93 BOİ 5 ve \%94 AKM giderimi ile çalışmaktadır. Mardin Su ve Kanalizasyon İdaresi Genel Müdürlüğü kontrolündeki Kızıltepe İleri Biyolojik Atıksu Arıtma Tesisi, Kentsel Atıksu Arıtma Yönetmeliği deşarj limitlerine göre değerlendirilmiştir.

Anahtar Kelimeler: Arıtma verimliliği, Atıksu, Biyolojik arıtma, İleri arıtma.

\section{Evaluation of Process Efficiency of Kiziltepe Advanced Biological Wastewater Treatment Plant in terms of COD, BOD 5 and SS}

\begin{abstract}
With the increasing world urbanization rate, domestic regional wastewater has becomeone of the leading leaders in the emergence of environmental pollution. Urban wastewater production facilities are facilities that have been constructed to avoid such pollution and preventor minimize the harmful effects of it before reaching to the receiving environment where the domestic wastewater will be transferred to. In this study, in The Kiziltepe Advanced Biological Wastewater Treatment Plant, the 24 hours composite samples taken from the entry and exit points of the facility on a daily basis during the 8 months of period were analyzed with the COD, BOD 5 and SS parameters and the resulting productivity was observed. Accordingly, the plant operates with $93 \%$ COD, $93 \%$ BOD 5 and $94 \%$ SS removal. The Kiziltepe Advanced Biological Wastewater Treatment Plant institution which is under the control of the General Directorate of Mardin Water and Sewerage Administration was evaluated according to the Urban Wastewater Treatment Regulations.
\end{abstract}

Keywords: Advanced treatment, Biological treatment, Treatment efficiency, Wastewater. 


\section{Giriş}

Canlılığın vazgeçilmez bir parçası olması nedeniyle artan nüfusla birlikte suya olan talep de gün geçtikçe artmaktadır. Yetersiz su kaynakları ve kaynakların kalitesinin bozulması Dünya'nın birçok yerinde kaygıyla karşılanmakta ve bu durumun yüzyılın başlıca sorunlarından biri olacağı uluslararası forumlarda açıkça belirtilmektedir. İçinde bulunduğumuz yüzyılın en önemli sorunlarından bir diğeri de iklim değişikliği ve buna bağlı olarak su kaynaklarının olumsuz etkilenmesidir. Dünya Su Geliştirme Raporu'na göre, 2050 yılında Dünya nüfusunun 9,3 milyar civarında olması beklenmektedir ve iklim değişikliği nedeniyle 7 milyar insanın su kıtlığı ile karşı karşıya geleceği raporlanmıştır (Duman, 2017).

Var olan su kaynakları, hayat standartları, toplumsal alışkanlıklar, ekonomik yaşam koşulları, iklim, eğitim seviyesi gibi birçok faktör, günlük su ihtiyaçlarının da değişiklik göstermesine neden olmaktadır. Kara, hava ve su kaynaklarından gelen kontrolsüz boşaltımlar araştırılmalı, tanımlanmalı ve alıcı ortamlara tesiri kontrol edilmelidir (Kanat vd., 2018). Teknoloji ve endüstrileşmenin paralelinde hızlıca gelişen kentleşme ile birlikte, çevrede görülen sosyal aktiviteler Türkiye' de gün geçtikçe ilerlemektedir (Akkoyunlu vd., 2017). Özellikle sanayi devriminden sonra gelişen kentleşme, endüstriyel ve zirai faaliyetler, suya olan talebi de beraberinde arttırmış ve buna bağlı olarak var olan temiz su kaynakları da kirlenerek kullanılamaz bir hal almıştır. Bu gibi faaliyetler sonucunda kirlenmiş veya fiziksel ve kimyasal karakteristikleri kısmen veya tamamıyla değişikliğe uğramış sular atıksu olarak tanımlanmaktadır (Eskikaya, 2018).

Kullanım amacı çeşitlilik kazanan su, birbirinden farklı özellikte atıksuların oluşmasına sebep olmuştur. Oluşan bu atıksular bir arıtma ünitesinden geçirilmeden doğal ortama deşarj edilirse en önemli kaynaklardan olan yeraltı sularının kirlenmesine, ekolojik dengenin de bozulmasına neden olacaktır. $\mathrm{Bu}$ sebeple kirliliği yüksek atıksuların doğru yöntemlerle arıtılması ve doğal ortama arıtımdan sonra deşarj edilmesi sürdürülebilir kalkınma amacı çerçevesinde önem kazanmaktadır (Boduroğlu, 2008). Suların çeşitli kullanımlar sonucunda atıksu haline dönüşerek yitirdikleri fiziksel, kimyasal ve bakteriyolojik özelliklerinin bir kısmını veya tamamını tekrar kazandırabilmek ve/veya boşaldıkları alıcı ortamın doğal fiziksel, kimyasal, bakteriyolojik ve ekolojik özelliklerini değiştirmeyecek hale getirebilmek için uygulanan fiziksel, kimyasal ve biyolojik arıtma işlemlerinin birini veya birkaçını uygulayarak atıksuların arıtılması gerekmektedir (SKKY, 2004).

Endüstriyel atıksuların özellikleri, üretim teknolojisi, çalışma prensibi ve proses suyunun çeşidi gibi faktörlerden büyük ölçüde etkilenmekte ve endüstriyel faaliyetin çeşidine göre atıksular tümüyle farklı özellikler gösterebilmektedir (Ayrak, 2010). Evsel atıksular, konutlardan, kurum ve kuruluşlardan gelen atıksular, yağmur suları, yüzeysel sular ve yeraltı sularının bileşimi olarak ifade edilebilir (Yıldırımer, 2006).

Atıksular arıtılmadan alıcı ortama bırakılırsa, bünyesindeki organik maddelerin ayrışması sonucu kötü kokular ortaya çıkar. İlaveten arıtılmamış atıksular bünyelerinde hastalık yapıcı mikroorganizmaları (patojenler), besi maddelerini (azot ve fosfor) ve tehlikeli maddeleri de içermektedir. Bu sebeple atıksuların arıtılarak bu zararlı ve tehlikeli maddelerin giderilmesi veya azaltılması gerekmektedir (Samsunlu, 2011). Atıksuların, barındırdıkları zararlı bileşenlerden arındırılmadan su yataklarına verilmesi ya da alıcı ortama deşarj edilmesi yüzeysel ve yeraltı sularını kirletmektedir. Evsel ve endüstriyel atıklar ile kontamine olmuş sular, atık cinsine, yeryüzü şekline, iklimsel şartlara, toprak yapısına ve zamana bağlı olarak alıcı ortamlarda ötrofikasyona neden olmaktadır (Gülsoy, 2017).

KOİ (kimyasal oksijen ihtiyac1), organik maddelerin kimyasal olarak oksitlenebilmesi için gerekli oksijen miktarı olarak ifade edilir ve asidik ortamda kuvvetli bir kimyasal oksitleyici yardımıyla ölçülür (Sinan, 2010). BOİ (biyolojik oksijen ihtiyac1), sudaki organik maddelerin 5 günde biyolojik olarak ayrıştırılması esnasında harcanan oksijen miktarını ifade eder. Kirleticilerin çevresel etkilerinin değerlendirilmesi ve arıtma tesislerinin tasarımında kullanılan önemli bir dizayn parametresidir. Organik maddelerin biyokimyasal oksidasyonu yavaş ilerleyen bir işlemdir ve teorik olarak sonsuza kadar sürer. Oksidasyon işleminin \%95-99'luk kısmı 20 günlük bir periyotta tamamlanır. Oksitlenmenin \%60-70’lik kısmı BOİ 5 ölçümünde kullanılan 5 günlük sürede gerçekleşir (Sinan, 2010). AKM (askıda katı madde), su numunelerinin standart filtre kağıdından süzülerek filtrenin kurutulmasıyla elde edilen kalıntıları ifade eder. AKM, suların fiziksel görünümü ile içme suyu ve endüstriyel amaçlarla kullanımını sınırlamaktadır. Suyun 1 şık geçirgenliğini azaltarak dip birikintilerine yol açar veya sudaki canlılara doğrudan zarar verir. $\mathrm{Bu}$ özellikleri ile AKM atıksularda önemli bir parametredir (Sinan, 2010).

$\mathrm{Bu}$ çalışmada, Kızıltepe İleri Biyolojik Atıksu Arıtma Tesisinde 8 ay boyunca tesis giriş ve çıkışından alınan 24 saatlik kompozit numunelerde KOİ, BOİ 5 ve AKM parametreleri analiz edilip, arıtma tesisinin giderim verimliliği gözlenmiştir. Tesis 2017 y1lında işletmeye alınan yeni bir tesis olmakla birlikte, çalışmamız, tesisin işletme verimliliği ile ilgili yapılan ilk çalışmadır ve bundan sonra tesisin çalışma verimliliğinin takibinde ve konu ile ilgili yapılacak diğer çalışmalarda yol gösterici olacaktır.

\section{Materyal ve Metot}

$\mathrm{Bu}$ çalışma kapsamında uygulama alanı olarak seçilen Kızıltepe İleri Biyolojik Atıksu Arıtma Tesisi, Mardin iline 27 $\mathrm{km}$ mesafedeki Kızıltepe ilçesinde yer almaktadır (Şekil 1). Atıksu arıtma tesisi (AAT) 2017 yılında işletmeye alınmıştır. 2032 y1lı için $64.749 \mathrm{~m}^{3} /$ gün, 2047 y1lı için $79.256 \mathrm{~m}^{3} /$ gün ortalama atıksu kapasitesi ile inşa edilmiştir. Tesis; fiziksel arıtma, biyolojik nütrient giderimi ve çamur çürütme, biyogaz eldesi ve yoğunlaştırma-susuzlaştırma bölümlerinden oluşmaktadır. Proses akış diyagramı Şekil 2'de gösterilmiştir.

Çalışma süresince KOİ, BOİ 5 ve AKM analizi yapılmıştır. KOİ ölçümleri Hach Lange DR3800 model spektrofotometre, BOİ ölçümleri ise Aqua Lytic AL606 BOİ cihazı ile yapılmıştır. AKM analizinde ise standart metotlar uygulanmıştır (APHA, 1998). 


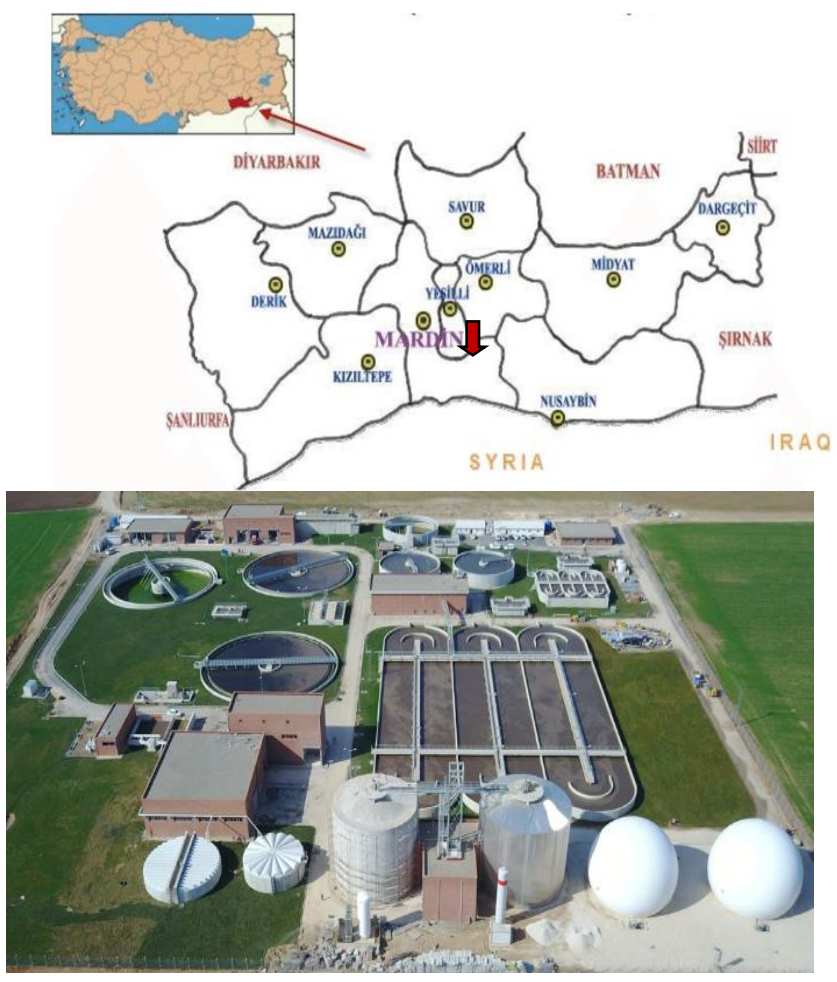

Şekil 1. Çalışma alanı

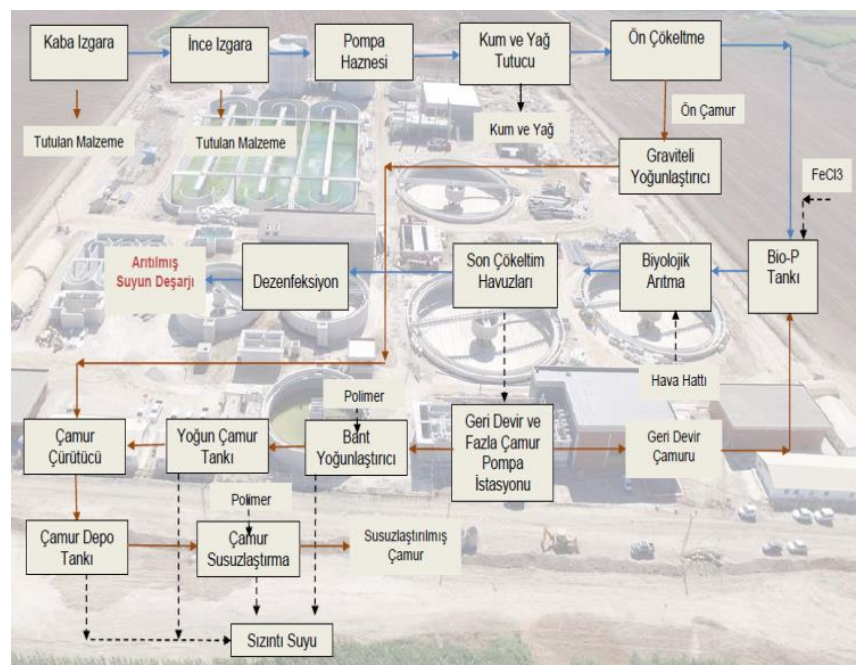

Şekil 2. Proses akış diyagramı

\section{Araştırma Sonuçları ve Tartışma}

Kızıltepe İleri Biyolojik AAT'de 8 ay boyunca günlük KOİ, $\mathrm{BOI}_{5}$ ve AKM parametreleri analiz edilip gözlemlenmiştir. Mardin $\mathrm{Su}$ ve Kanalizasyon İdaresi Genel Müdürlüğü kontrollüğündeki Kızıltepe İleri Biyolojik AAT’nin deşarj limitleri 08.01.2006 tarih 26047 sayılı Kentsel Atıksu Arıtma Yönetmeliği'ne göre değerlendirilmiştir. Tablo 1'de Kentsel Atıksu Arıtma Yönetmeliği deşarj limitleri gösterilmiştir (Anonim, 2006).

\subsection{KOİ Arıtım Verimi}

Kızıltepe AAT'nin giriş ve çıkış sularından 2018 yılının Eylül ayından 2019 yılının Nisan ayına kadar alınan 24 saatlik kompozit numuneler analiz edilmiştir. Günlük yapılan analiz sonuçlarının aylık ortalama değeri alınarak tesis verimliliği gözlemlenmiştir. KOİ aylık ortalama değerleri Tablo 2'de verilmiştir.

Tablo 1.Kentsel Atıksu Arıtma Yönetmeliği deşarj limitleri(Anonim, 2006)

\begin{tabular}{ccc}
\hline Parametreler & $\begin{array}{c}\text { Konsantrasyon } \\
(\mathbf{m g} / \mathbf{l})\end{array}$ & $\begin{array}{c}\text { Minimum arıtma } \\
\text { verimi }(\%)\end{array}$ \\
\hline $\begin{array}{c}\text { Biyokimyasal oksijen } \\
\text { ihtiyac1 }\end{array}$ & 25 & $70-90$ \\
$\left(20^{\circ} \mathrm{C}^{\prime}\right.$ de BOİ $)$ & & \\
$\begin{array}{c}\text { Kimyasal oksijen } \\
\text { ihtiyac1 (KOİ) }\end{array}$ & 125 & 75 \\
$\begin{array}{c}\text { Toplam askida kat1 } \\
\text { madde (TAKM) }\end{array}$ & $\begin{array}{c}\text { E.N.'den fazla) } \\
60 \text { (2000-10000 } \\
\text { E.N. })\end{array}$ & $\begin{array}{c}\text { E.N.'den fazla) } \\
70(2000-10000 \\
\text { E.N. })\end{array}$ \\
\hline
\end{tabular}

Tablo 2. AAT giriş-çıkış suyu KOİ konsantrasyonları ve giderim verimleri

\begin{tabular}{cccc}
\hline Tarih & $\begin{array}{c}\text { Giriş KOI் } \\
\text { değeri (mg/L) }\end{array}$ & $\begin{array}{c}\text { Çıkış KOI } \\
\text { değeri (mg/L) }\end{array}$ & $\begin{array}{c}\text { Verimlilik } \\
(\mathbf{\%})\end{array}$ \\
\hline Eylül 2018 & 562 & 30 & 94 \\
Ekim 2018 & 406 & 34 & 91 \\
Kasım 2018 & 326 & 33 & 90 \\
Aralık 2018 & 339 & 27 & 91 \\
Ocak 2019 & 399 & 26 & 93 \\
Şubat 2019 & 439 & 23 & 94 \\
Mart 2019 & 429 & 21 & 95 \\
Nisan 2019 & 482 & 32 & 94 \\
Ortalama & $\mathbf{4 3 0}$ & $\mathbf{2 8}$ & $\mathbf{9 3}$ \\
\hline
\end{tabular}

Tablo 2 incelendiğinde, çıkış suyunda ölçülen KOİ konsantrasyonlarının 8 ay boyunca deşarj limiti olan 125 mg/L'nin altında kaldığ 1 görülmektedir. KOİ giriş değerinin en yüksek olduğu ay Eylül 2018, en düşük olduğu ay ise Aralık 2018; KOİ çıkış değerinin en yüksek olduğu ay Ekim 2018, en düşük olduğu ay ise Mart 2019 olarak ölçülmüştür. Bu verilere göre, tesis KOİ giderim veriminin Kentsel Atıksu Arıtımı Yönetmeliğinin deşarj limitine uygunluğu gözlenmiştir (Tablo 1) (Anonim, 2006).

Şama (2017) tarafindan yapılan çalışmada Ocak 2014Haziran 2015 tarihleri arasında Taşköprü AAT'nin giriş ve çıkış sularından alınan 2 saatlik kompozit numuneler ile KOİ verimlilik analizleri yapılmıştır. Bu analizlere göre 18 aylık KOİ giderim verimi; min. \%84.8, max. \%97.2 ve ort. \%94.3 olarak bulunmuştur. Azman (2005) tarafindan yapılan çalışmada ise Kasım 2013 tarihinde 1 aylık Ankara merkezi AAT'nde giriş ve çıkış sularından alınan 24 saatlik kompozit numunelerde KOİ analizleri yapılmıştır. Bu analizlere göre 1 aylık KOİ giderim verimi; min. $\% 85$, max. $\% 96$ ve ort. $\% 90$ olarak belirlenmiştir. Tanyol ve Uslu (2013), Tunceli ili Evsel AAT'nin giriş ve çıkışında KOİ değişimini Nisan-Haziran 2013 ayları arasında incelemişlerdir. Yapılan analizlere göre KOİ giderim verimi; min. $\% 82$, max. $\% 95$ ve ort. \%90'dır. SKKY'ne göre nüfusu 10000-100000 kişi olan yerleşim merkezlerinin evsel nitelikli atıksularının alıcı ortama deşarj standardı, 2 saatlik kompozit örnekte KOİ için 140 mg/L'dir. Standartlarla karşılaştırıldığında 
deşarj edilen KOİ konsantrasyonlarının standartların altında olduğunu belirlemişlerdir. Öz (2009) tarafindan yapılan çalışmada, Akzo Nobel-Marshall Ortak Endüstriyel AAT'nde Mart 2008, Mayıs 2008 ve Ocak 2009 aylarında tesis giriş ve çıkış noktalarından kompozit 2 saatlik örnekler alınmış olup KOİ analizleri SM 5220- Açık Refluks yöntemine göre yapılmıştır. KOİ giderim verimini \%98 olarak belirlemiştir. Topal ve Arslan Topal (2011) tarafından yapılan çalışmada 20102011 kış sezonunda Elazığ Belediyesi AAT'nde KOİ parametresinin değişimleri gözlemlenmiştir. $\mathrm{Su}$ Kirliliği Kontrolü Yönetmeliği'ne göre KOİ konsantrasyonu sınır değer $120 \mathrm{mg} / \mathrm{L}$ olarak verilmiştir (Tablo 1) (Anonim, 2006). 2010$2011 \mathrm{k}$ ş sezonunda 24. gün $124 \mathrm{mg} / \mathrm{L}$ olarak ölçülerek deşarj standardının üstünde olduğu, 24. gün dışında diğer günlerin uygun olduğu izlenmiştir. Doğan (2010) tarafından yapılan tez çalışmasında; 10 farklı atıksu arıtım tesisinde mevsimsel olarak KOİ verimini gözlemiştir. En düşük verimlilik genel olarak kış aylarında yaşanmış olup İzmir-Çiğli AAT’nde \%72 olarak gözlenmiştir. En yüksek verim ise genel olarak yaz aylarında yaşanmış olup ilkbahar aylarında Kayseri AAT'nde \%98 olarak gözlenmiştir.

\subsection{BOİ5 Arıtım Verimi}

Kızıltepe AAT'nin giriş ve çıkış sularından 2018 yılının Eylül ayından 2019 yılının Nisan ayına kadar alınan 24 saatlik kompozit numuneler analiz edilmiştir. Günlük yapılan analiz sonuçlarının aylık ortalama değeri alınarak arıtım verimliliği gözlenmiştir. Aylık ortalama $\mathrm{BOI்}_{5}$ değerleri Tablo 3 'de verilmiştir.

Tablo3. AAT giriş-çıkış suyu BOI $\dot{B}_{5}$ konsantrasyonları ve giderim verimleri

\begin{tabular}{cccc}
\hline Tarih & $\begin{array}{c}\text { Giriş BOİ5 } \\
\text { değeri (mg/L) }\end{array}$ & $\begin{array}{c}\text { Çıkış BOİ5 } \\
\text { değeri (mg/L) }\end{array}$ & $\begin{array}{c}\text { Verimlilik } \\
(\mathbf{\%})\end{array}$ \\
\hline Eylül 2018 & 414 & 19 & 95 \\
Ekim 2018 & 301 & 23 & 92 \\
Kasım 2018 & 259 & 23 & 91 \\
Aralık 2018 & 229 & 19 & 91 \\
Ocak 2019 & 270 & 17 & 93 \\
Şubat 2019 & 310 & 15 & 95 \\
Mart 2019 & 297 & 14 & 95 \\
Nisan 2019 & 332 & 21 & 94 \\
Ortalama & $\mathbf{3 0 1}$ & $\mathbf{1 9}$ & $\mathbf{9 3}$ \\
\hline
\end{tabular}

Tablo 3 incelendiğinde, çıkış suyunda ölçülen BOİ konsantrasyonlarının 8 ay boyunca deşarj limiti olan 25 mg/L'nin altında kaldığı görülmektedir $\mathrm{BOI}_{5}$ giriş değerinin en yüksek olduğu ay Eylül 2018, en düşük olduğu ay ise Aralık 2018, BOİ 5 çıkış değerinin en yüksek olduğu ay Ekim 2018, en düşük olduğu ay ise Mart 2019 olarak belirlenmiştir. Bu verilere göre, tesis $\mathrm{BOI}_{5}$ giderim veriminin Kentsel Atıksu Arıtımı Yönetmeliğinin deşarj limitine uygunluğu gözlenmiştir (Tablo 1) (Anonim, 2006).

Şama (2017) tarafından yapılan çalışmada Ocak 2014Haziran 2015 tarihleri arasında Taşköprü AAT'nin giriș ve çıkıș sularından alınan 2 saatlik kompozit numuneler ile $\mathrm{BOI}_{5}$ verimlilik analizleri yapılmıştır. Bu analizlere göre 18 aylık BOI் giderim verimi; min. \%83.3, max. \%98 ve ort. \%94.2 olarak tespit edilmiştir. Azman (2005) tarafından yapılan çalışmada ise Kasım 2013 tarihinde 1 aylık Ankara merkezi AAT’nde giriş ve çıkış sularından alınan 24 saatlik kompozit numunelerde $\mathrm{BOI}_{5}$ analizleri yapılmıştır. $\mathrm{Bu}$ analizlere göre 1 aylık $\mathrm{BO} \dot{I}_{5}$ giderim verimi; min. \%91, max. \%97 ve ort. \%94,97 olarak bulunmuştur. Tanyol ve Uslu (2013) tarafindan Tunceli ili evsel AAT'nin arıtma verimini incelemek amacıyla tesis giriş ve çıkışında $\mathrm{BOI}_{5}$ değişimi, Nisan-Haziran 2013 ayları arasında incelenmiştir. Yapılan analizlere göre $\mathrm{BOI்}_{5}$ giderim verimi; min. \%83, max. $\% 93$ ve ort. $\% 93$ olarak belirlenmiştir. Standartlarla karşılaştırıldığında deşarj edilen $\mathrm{BOI}_{5}$ konsantrasyonları standartların altında olduğunu belirtmişlerdir. Öz (2009) tarafindan yapılan çalışmada Akzo Nobel-Marshall Ortak Endüstriyel AAT'nde Mart 2008, Mayıs 2008 ve Ocak 2009 aylarında tesis giriş ve çıkış noktalarından kompozit 2 saatlik numuneler alınmış olup, BOİ 5 analizleri SM 5210 yöntemine gore yapılmıştır. Sistemin $\mathrm{BOI}_{5}$ giderim verimi \%96.8 olarak belirlemiştir. Doğan (2010) tarafından yapılan tez çalışmasında; 10 farklı atıksu arıtım tesisinde mevsimsel olarak $\mathrm{BOI}_{5}$ verimi gözlenmiştir. En düşük verimlilik genel olarak kış aylarında yaşanmış olup İzmir-Çiğgli AAT'nde $\% 85$, en yüksek verim ise genel olarak yaz aylarında yaşanmış olup ilkbahar aylarında Kayseri AAT’nde \%99 olarak gözlenmiştir.

\subsection{AKM Aritım Verimi}

Kızıltepe AAT'nin giriş ve çıkış sularından 2018 yılının Eylül ayından 2019 yılının Nisan ayına kadar alınan 24 saatlik kompozit numuneler analiz edilmiştir. Günlük yapılan analiz sonuçlarının aylık ortalama değeri alınarak AKM verimliliği gözlenmiştir. Aylık ortalama AKM değerleri Tablo 4'de verilmektedir.

Tablo 4. AAT giriş-çıkış suyu AKM konsantrasyonları ve giderim verimleri

\begin{tabular}{|c|c|c|c|}
\hline Tarih & $\begin{array}{c}\text { Giriş AKM } \\
\text { değeri }(\mathrm{mg} / \mathrm{L})\end{array}$ & $\begin{array}{c}\text { Çıkış AKM } \\
\text { değeri (mg/L) }\end{array}$ & $\begin{array}{c}\text { Verimlilik } \\
(\%)\end{array}$ \\
\hline Eylül 2018 & 471 & 17 & 96 \\
\hline Ekim 2018 & 403 & 18 & 95 \\
\hline Kasım 2018 & 305 & 18 & 94 \\
\hline Aralık 2018 & 285 & 18 & 93 \\
\hline Ocak 2019 & 401 & 22 & 94 \\
\hline Şubat 2019 & 462 & 21 & 95 \\
\hline Mart 2019 & 398 & 20 & 94 \\
\hline Nisan 2019 & 512 & 42 & 92 \\
\hline Ortalama & 405 & 22 & 94 \\
\hline
\end{tabular}
konsantrasyonlarının Kentsel Atıksu Arıtımı Yönetmeliği deşarj limitine uygun olduğu gözlenmiştir (Tablo 1) (Anonim, 2006). AKM giriş değerinin en yüksek olduğu ay Nisan 2019 en düşük olduğu ay ise Aralık 2018, AKM çıkış değerinin en yüksek olduğu ay Nisan 2019, en düşük olduğu ay ise Eylül 2018 olarak ölçülmüştür.

Şama (2017) tarafından yapılan çalışmada Ocak 2014Haziran 2015 tarihleri arasında Taşköprü AAT'nin giriş ve çıkış sularından alınan 2 saatlik kompozit numuneler ile AKM verimlilik analizleri yapılmıştır. $\mathrm{Bu}$ analizlere göre 18 aylık AKM giderim verimi; min. \%73.3, max. \%95.5 ve ort. \%90'dır. Yapılan çalışmanın deşarj limitinin altında olduğunu göstermekte olup Kentsel Atıksu Arıtımı Yönetmeliğinin deşarj limitine uygunluğunu gözlemlemiştir (Tablo 1) (Anonim, 2006). 2015 yılının Ocak ayında hesaplanan ortalama giderim veriminin \%73.3 olmasının nedeni giriş suyundaki kirlilik yüklerindeki düşüşten dolayı verimin düşüşüne neden olduğunu belirtmiştir. 
Azman (2005) tarafından yapılan çalışmada ise Kasım 2013 tarihinde 1 aylık Ankara merkezi AAT'nde giriş ve çıkış sularından alınan 24 saatlik kompozit numunelerde Standart Metod 2540 ile AKM analizleri yapılmıştır. Bu analizlere göre 1 aylık AKM giderim verimi; min. \%88, max. \%97 ve ort. $\% 93.26$ olarak bulunmuştur. Tanyol ve Uslu (2013) tarafindan yapılan çalışmada Tunceli ili evsel AAT'nin arıtma verimini incelemek amacıyla tesis giriş ve çıkışında AKM değişimi Nisan-Haziran 2013 ayları arasında incelenmiştir. Yapılan analizlere göre AKM giderim verimi; $\min \% 86$, $\max$. $\% 94$ ve ort. \%84'tür. Standartlarla karşılaştırıldığında deşarj edilen AKM konsantrasyonlarının standartların altında olduğunu belirlemişlerdir. Öz (2009) tarafından yapılan çalışmada Akzo Nobel-Marshall Ortak Endüstriyel AAT'nde Mart 2008, Mayıs 2008 ve Ocak 2009 aylarında tesis giriş ve çıkış noktalarından kompozit 2 saatlik örnekler alınmış olup AKM analizleri SM 2540-D $103-105^{\circ} \mathrm{C}$ kurutma ile toplam askıda katı madde tayin yöntemine gore yapılmıştır. Sistemin AKM giderim verimi \%97.83 olarak belirlemiştir. Tesisin AKM giderim veriminin, yaz mevsiminde diğer mevsimlere göre daha yüksek olduğu görülmüştür. Topal ve Arslan Topal (2011) tarafindan yapılan çalışmada 2010-2011 kış sezonunda Elazı̆̆ Belediyesi AAT'nin bazı parametrelerle değerlendirmesi yapılmıştır. Bu çalışmada 2010-2011 kışsezonunda AKM parametresinin değişimleri gözlenmiştir. En yüksek AKM giderim verimi Şubat ayında gerçekleşmiş olup \%96,3 giderim sağlanmıştır. En düşük AKM giderim verimi ise yine Şubat ayında \%90 olarak gerçekleşmiştir. AKM konsantrasyonunun yönetmelikte belirlenen sınır değerin altında kaldığını belirtmişlerdir (Tablo 1) (Anonim, 2006). Doğan (2010) tarafından yapilan tez çalışmasında; 10 farklı atıksu arıtım tesisinde mevsimsel olarak AKM verimi gözlenmiştir. En düşük verimlilik genel olarak kış aylarında yaşanmış olup İzmir-Çiğli AAT'nde \%83, en yüksek verim ise genel olarak yaz aylarında yaşanmış olup sonbahar aylarında Lara AAT’nde \%99 olarak gözlenmiştir.

\section{Sonuç}

$\mathrm{Bu}$ çalışmada Kızıltepe İleri Biyolojik Atıksu Arıtım Tesisi'nde 8 ay boyunca günlük tesis giriş ve çıkışından alınan 24 saatlik kompozit numuneler ile KOİ, BOİ 5 ve AKM parametreleri analiz edilip giderim verimliliği gözlenmiştir.

KOİ parametresinin 8 aylık ortalama giriş değeri 429.83 $\mathrm{mg} / \mathrm{L}$ çıkış değeri ise $28.10 \mathrm{mg} / \mathrm{L}$ 'dir. 8 aylık ortalama KOİ konsantrasyonun verimliliği \%92.67 olarak hesaplanmıştır.

$\mathrm{BOI}_{5}$ parametresinin 8 aylık ortalama giriş değeri $400 \mathrm{mg} / \mathrm{L}$ çıkış değeri ise $25 \mathrm{mg} / \mathrm{L}$ 'dir. 8 aylık ortalama $\mathrm{BOİ}_{5}$ konsantrasyonun verimliliği \%92 olarak hesaplanmıştır.

AKM parametresinin 8 aylık ortalama giriş değeri 404.71 $\mathrm{mg} / \mathrm{L}$ çıkış değeri ise $22.14 \mathrm{mg} / \mathrm{L}$ 'dir. 8 aylık ortalama AKM konsantrasyonun verimliliği \%94.10 olarak hesaplanmıştır.

Elde edilen sonuçlara göre tesis, KOİ, $\mathrm{BOI்}_{5}$ ve AKM parametreleri bakımından Kentsel Atıksu Arıtma Yönetmeliğinin deşarj limitlerine uygun olarak işletilmektedir (Anonim, 2006).

\section{Kaynakça}

Akkoyunlu, A., Avsar, Y., Erguven, G.O. 2017. Hazardous Waste Management in Turkey. Journal of Hazardous Toxic and Radioactive Waste, 21(4): 04017018.
Anonim (2006). Kentsel Atıksu Arıtma Yönetmeliği. Çevre ve Orman Bakanlı̆̆ , Ankara, Türkiye.

APHA, 1998. Standart Methods for the Examination of Water and Wastewater, 20th Edition. American Public Health Association, Washington, D.C.

Ayrak, B. 2010. Evsel atıksuların aritılması ve maliyet analizi. Gebze Yüksek Teknoloji Enstitüsü Mühendislik ve Fen Bilimleri Enstitüsü, Gebze-Kocaeli, Türkiye, 83s.

Azman, H.E. 2005. Evsel atıksuların arıtılmasında arıtma verimi-enerji ilişkisinin incelenmesi. Çukurova Üniversitesi Fen Bilimleri Enstitüsü, Adana, Türkiye, 95s.

Boduroğlu, B.H. 2008. Evsel atıksuların arıtması ve havalandırma parametlerininincelenmesi. Gazi Üniversitesi Fen Bilimleri Enstitüsü, Ankara, Türkiye, 57s.

Doğan, F. 2010. Mevcut atıksu arıtma tesislerinin fosfor giderimi için rehabilitasyon seçeneklerin değerlendirilmesi. Çevre ve Orman Bakanlığ Çevre Yönetimi Genel Müdürlüğ̈̈ Su ve Toprak Yönetimi Dairesi Başkanlığ , Türkiye, 163s.

Duman, H. 2017. Arıtılmış kentsel atıksuların sulamada yeniden kullanımı kayseri atıksu arıtma tesisi örneği. Orman ve Su Işsleri Bakanlı̆̆ Su Yönetimi Genel Müdürlüğ̈̈. Ankara, Türkiye, 100s.

Eskikaya, B.O. 2018. Kahramanamaraş merkez atıksu arıtma tesisi giriş atıksuyukarakterizasyonu. Kahramanmaraş Sütçü Imam Üniversitesi Fen Bilimleri Enstitüsü, Kahramanamaraş, Türkiye, 59s.

Gülsoy, İ. 2017. Kentsel atıksu arıtma tesisinin online izlenmesi ile enerji etüt ve optimizasyonu. Kocaeli Üniversitesi Fen Bilimleri Enstitüsü, Kocaeli, Türkiye, 97s.

Kanat, G., Ikizoglu, B., Erguven, G.O., Akgun, B. 2018. Determination of Pollution and Heavy Metal Fractions in Golden Horn Sediment Sludge (Istanbul, Turkey). Polish Journal of Environmental Studies, 27(6): 2605-2611.

Öz, A. 2009. Atıksu arıtma tesislerinde verimlilik kontrolü ve işletme sorunları. Kocaeli Üniversitesi Fen Bilimleri Enstitüsü, Kocaeli, Türkiye, 119s.

Samsunlu, A. 2011. Atıksuların Arıtılmas1, Birsen Yayınevi, İstanbul.

Sinan, R.K. 2010. Evsel atıksu arıtma tesislerinde ön arıtım ve biyolojik arıtım çıkış parametrelerinin YSA ile tahmini. Selçuk Üniversitesi Fen Bilimleri Enstitüsü, Konya, Türkiye, 140 s.

SKKY, 2004. 31.12.2004 tarih ve 25867 sayllı Resmi Gazete.

Şama, A. 2017. Taşköprü (Kastamonu) atıksu arıtma tesisi için proje aşamasında öngörülen ve mevcut durumda sağlanan verimin sürekliliğinin karşılaştırılması. İller Bankası Anonim Şirketi, Türkiye, 129s.

Tanyol, M., Uslu, G. 2013. Tunceli evsel atıksu arıtma tesisinin arıtma etkinliğinin değerlendirilmesi. Mehmet Akif Ersoy Üniversitesi Fen Bilimleri Enstitüsü Dergisi, 4(2), 24-29.

Topal, M., Arslan Topal, E.I. 2011. 2010-2011 kış sezonunda Elazığ Belediyesi Atıksu Arıtma Tesisi'nin bazı parametrelerle değerlendirilmesi. Cumhuriyet Üniversitesi Fen Fakültesi Fen Bilimleri Dergisi, 32(2), 12s.

Yıldırımer, A.K. 2006. Evsel atıksu arıtma tesislerinde debimaliyet ilişkileri. Çukurova Üniversitesi Fen Bilimleri Enstitüsü, Adana, Türkiye, 126s. 